\title{
Fenomen \\ Wielkiego Księstwa Litewskiego - koegzystencja kultur. Przekłady Koranu na język polski
}

DOI: http://dx.doi.org/10.12775/LC.2016.017

\begin{abstract}
Streszczenie. Wielkie Księstwo Litewskie jest w dziejach Europy unikalnym przykładem pokojowej koegzystencji wielu narodowości, kultur i religii. Od XIV w. swoje losy związali z ziemiami Księstwa tatarscy osadnicy, reprezentujący typ kultury inkluzywnej - otwartej na zewnętrzne wplywy kulturowe. Pełna asymilacja z chrześcijańskim otoczeniem znalazła wyraz w materialnym i niematerialnym dziedzictwie kulturowym tej grupy etnicznej, do którego należą zarówno obiekty architektoniczne, jak i osobliwa literatura religijna, w tym pierwszy w Europie przekład Koranu na języki słowiańskie. Bezpośrednią implikacją panującej w dawnej Rzeczypospolitej tolerancji kulturowej była również współpraca katolików (filomatów wileńskich) i muzułmanów (Tatarów Wielkiego Księstwa Litewskiego) w zakresie tłumaczenia i wydania XIX-wiecznej translacji świętej Księgi islamu.

Słowa kluczowe: polszczyzna północnokresowa, przekładoznawstwo, kitabistyka, tłumaczenia Koranu na języki słowiańskie, Wielkie Księstwo Litewskie
\end{abstract}

Abstract. In the history of Europe, the Grand Duchy of Lithuania is a unique example of peaceful coexistence of nations, cultures and religions. Since the $14^{\text {th }}$ century, the Tatar settlers shared their lot with the land of the Duchy, and they represented the type of an inclusive culture - open to external cultural influences. The full assimilation with the Christian environment found its expression in material and nonmaterial cultural heritage of that ethnic group; among other things, there

* Joanna Kulwicka-Kamińska - dr hab. nauk humanistycznych w zakresie językoznawstwa, kierownik Zakładu Historii Języka Polskiego, Centrum Badań Kitabistycznych i Podyplomowego Studium Logopedii Uniwersytetu Mikołaja Kopernika w Toruniu. Prowadzi prace badawcze z zakresu językoznawstwa diachronicznego i kontrastywnego (historia języka polskiego, w tym staro-i średniopolski system fleksyjny oraz słowiańsko-orientalne relacje językowe, m.in. zapożyczenia do polszczyzny z języków arabskiego, tureckiego i perskiego, teolingwistyka, kitabistyka) i translatoryki (przekład na język polski terminologii religijnej islamu i chrześcijaństwa). E-mail: asiakk2@o2.pl. 
are undoubtedly both architectonic objects and examples of specific religious literature, including the first European Quran's translation into Slavic languages.

Keywords: language variety spoken at the Polish-Lithuanian-Belarusian borderland, translation studies, kitabistics, Quran's translation on Slavic languages, Grand Duchy of Lithuania

\section{Unia Polski z Litwą}

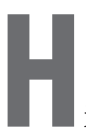

istoria unii Polski z Litwą sięga aktu w Krewie (1385) i wiąże się z chrztem Litwy w obrządku katolickim (1386/1387). Unia personalna między obu krajami, umocniona za Kazimierza Jagiellończyka, funkcjonuje przez blisko 200 lat, zbliżając do siebie dwie organizacje państwowe, $w$ rezultacie tworząc jeden organizm polityczny - Rzeczpospolitą Obojga Narodów. W 1569 r. przekształcono bowiem unię personalną Polski z Litwą w unię realną, niezwiązaną z dynastią królewską, jeszcze mocniejszą i niejako obiektywnie zrównującą prawa obu narodów. Polska i Litwa miały wspólną władzę ustawodawczą przy zachowaniu odrębności narodowej. Litwa dysponowała urzędami centralnymi (w tym skarbem i wojskiem), a jej ustrój upodobnił się do polskiego - jeden senat, wspólny sejm, podział Wielkiego Księstwa Litewskiego (dalej: WKL) na województwa.

Unia lubelska zniosła granice polityczne między Litwą a Polską, tym samym dopuściła do swobodnego przemieszczania się ludności jako obywateli jednej Rzeczypospolitej. Mogli oni osiedlać się na dowolnym terytorium i piastować tam urzędy. Powstała zatem wielonarodowościowa polsko-litewsko-białorusko-ruska rzeczpospolita szlachecka, w której można było wyróżnić trzy równorzędne dzielnice: Wielkopolskę z Prusami, Małopolskę z Rusią i WKL. Szlachta litewska i ruska (bojarstwo litewsko-ruskie) otrzymała wszystkie prawa szlachty polskiej.

Unia przyczyniła się do postępu cywilizacyjnego w WKL. Było ono wówczas fenomenem na skalę światową w zakresie chociażby tolerancji etnicznej czy religijnej. Co ciekawe, działo się to w okresie wojen religijnych za czasów reformacji. Tolerancja religijna w Rzeczypospolitej, zwłaszcza w dobie panowania Zygmunta Augusta (m.in. na mocy nadanego przez niego przywileju w Toruniu odbyło się pierwsze publiczne nabożeństwo ewangelickie - 25 marca 1557, a na podstawie wydanego w Wilnie przywileju dopuszczono prawosławnych do najwyższych urzędów WKL - 7 lipca 1563 r.), przyczyniła się do uznania go przez Tatarów WKL za kalifa - religijny autorytet i przywódcę ${ }^{1}$. Należy dodać, że król był unitarianinem ${ }^{2}$, zatem jego poglądy religijne pozostawały Tatarom szczególnie bliskie. Postawa Zygmunta Augusta wyraźnie kontrastowała przy tym z postawą radykalnych w poglądach protestantów w Europie Zachodniej. Król wypowiedział m.in. słowa: „Nie jestem panem waszych sumień”, a Polska była państwem „bez stosów”.

\footnotetext{
1 Por. S. Kryczyński, Zygmunt August a Tatarzy litewscy, ,Przegląd Islamski” 1934, z. 3/4.

2 W. Martin, Świat religii i sekt, Warszawa 2004, s. 753.
} 


\section{Osadnictwo tatarskie na ziemiach Wielkiego Księstwa Litewskiego}

Można wyróżnić kilka etapów osadnictwa Tatarów na ziemiach WKL. Pierwsza fala osadników tatarskich przybyła na Litwę ze Złotej Ordy (historycznego państwa mongolskiego, założonego ok. 1240 r. w zachodniej części imperium Czyngis-chana przez jego wnuka Batu-chana. Obejmowało: Powołże, część Kaukazu, Krym, stepy nad Morzem Czarnym, Ural, zachodnią Syberię oraz część Azji Środkowej) za czasów panowania chana Uzbeka (1312-1342), prowadzącego politykę przymusowej islamizacji swoich poddanych. Ci zatem, którzy chcieli pozostać przy wierze przodków - szamanizmie - uciekali do pogańskiej Litwy. Jednakże „ślad po nich zaginął” - ochrzcili się wraz z Litwą.

Kolejny etap to czas panowania na Litwie księcia Witolda (1392-1430). Osadnicy tatarscy rekrutowali się wówczas z jeńców wojennych, pojmanych m.in. podczas bitwy pod Worsklą (1397). Ich umiejętności bojowe wykorzystano później w walkach z Krzyżakami. Śmierć księcia Witolda nie przerwała procesu osiedlania się Tatarów na ziemiach WKL. Wśród wychodźców można wskazać m.in. członków możnych rodów chanatów krymskiego i kazachskiego.

Ostatnia fala osadników napłynęła w 2. poł. XVI i na początku XVII w. Była to ludność tatarska pochodząca z dawnych chanatów kazańskiego i astrachańskiego, zajętych przez Rosję. W późniejszym okresie Tatarzy również emigrowali do Rzeczypospolitej, jednakże ich napływ nie miał tak masowego charakteru jak do XVII w. (źródła podają bowiem liczbę 200000 osadników) $)^{3}$.

\section{Tolerancja}

W XVI stuleciu położenie prawne społeczności tatarskiej wyznaczały statuty litewskie, przywileje wielkich książąt litewskich, konstytucje sejmowe, reskrypty króla i jego urzędników, kontrakty właścicieli dóbr oraz stosunki społeczne i prawne panujące na Litwie. Przebywając w WKL, Tatarzy zachowali autonomię w trzech zasadniczych sprawach. Utrzymali własny samorząd, wolność wyznania, prawo do budowy meczetów oraz własną strukturę organizacji społecznej w postaci chorąstw tatarskich. Swoistą sytuację prawną Tatarzy uzyskali dzięki przywilejom królewskim. Przywilej Zygmunta Augusta z 24 czerwca 1568 r. gwarantował im nienaruszalność dawniejszych praw i przywilejów; przywilej Władysława IV z 21 czerwca 1634 r. podnosił odwagę Tatarów podczas wyprawy moskiewskiej i potwierdzał ich dotychczasowe prawa oraz wolności. W 1659 r. król Jan Kazimierz obdarował Tatarów koronnych prawami i wolnościami dotąd przysługującymi Tatarom litewskim. Natomiast w 1662 r. zezwolił Tatarom pełniącym służbę wojskową na zakup ziemi

3 J. Talko-Hryncewicz, Muślimowie, czyli tak zwani Tatarzy litewscy, „Bibljoteczka geograficzna Orbis” 1924, serja III, t. VII, s. 111-118. 
szlacheckiej. Jan III Sobieski przywilejem z dnia 24 marca 1677 r. zagwarantował Tatarom posiadanie służby chrześcijańskiej.

Sytuację prawną Tatarów kształtowały również konstytucje sejmowe. W latach 1607-1786 wydano kilkanaście tzw. konstytucji tatarskich. Poruszały one sprawę posługi wojennej Tatarów z nadanej im ziemi, pogłównego tatarskiego, najmu czeladzi chrześcijańskiej oraz trzymania przez nich dóbr królewskich i szlacheckich, a także stawiania nowych meczetów i naprawy podupadłych w nowych osiadłościach. Najwięcej ustaw dotyczyło kwestii służby tej ludności w wojsku Rzeczypospolitej za pieniądze ${ }^{4}$.

$\mathrm{Z}$ czasem niwelowały się zatem różnice obyczajowe oraz językowe między Tatarami i autochtonami, zwłaszcza że „osadnicy tatarscy stanowili odbicie etnicznej, socjalnej i kulturowej złożoności Złotej Ordy”’ Ponadto posługiwali się różnymi dialektami kipczackimi. Reprezentowali więc typ kultury inkluzywnej, który implikował szybko postępującą asymilację z chrześcijańskim otoczeniem. Tekst Traktatu o Tatarach polskich, pochodzący z $1558 \mathrm{r}$. (sporządzony w języku tureckim przez anonimowego Tatara, pielgrzyma do Mekki, dla Rustema Paszy, zięcia sułtana tureckiego), potwierdza to, iż w WKL Tatarzy posługiwali się językami polskim i białoruskim, o czym świadczy chociażby poniższy cytat: „[...] a jeżeli nasi nie mogą rozmawiać po arabsku lub turecku, za to mają znajomość innych języków: każdy bowiem w naszym kraju posiada dwie mowy, tam powszechnie używane"6.

Tak więc wyznający islam Tatarzy utracili znajomość swych etnicznych (turkijskich) dialektów, a w warunkach izolacji od źródeł i korzeni islamu - utracili także czynną znajomość liturgicznego języka arabskiego. Arabskie teksty religijne, których musieli używać ze względów doktrynalnych, stały się dla nich tym samym niezrozumiałe. Pełna asymilacja językowa i związana z nią trudność, a z czasem nawet niemożność poznania, i zrozumienia zasad islamu należały do głównych przyczyn powstania „literatury tatarskiej” w językach słowiańskich.

Utrzymanie odrębności etnicznej i tożsamości kulturowej, którą już w XVI w. identyfikowano wyłącznie poprzez islam, miało zapewnić Tatarom piśmiennictwo religijne.

\section{Tatarskie piśmiennictwo religijne}

$\mathrm{Na}$ świecie prowadzone są badania nad literaturą typu aljamiado (z ar. al- 'ağamiyya „obca”; od al-luḡa al- "ağamiyya „język obcy”). Obejmują one twórczość w języku miejscowym, zapisywaną odpowiednio przystosowanym alfabetem arabskim i rozwijającą się pod silnym wpływem tradycji i kultury islamu. Charakterystyce tej odpowiada np. literatura muzulmańska w zachodniej i południowej Afryce, literatura aljamiado na Półwyspie Iberyjskim, muzułmańskie teksty serbskie w Bośni i Hercegowinie, literatura albańskich bejtedżinów.

\footnotetext{
4 Por. ustalenia w tym zakresie K. Grygajtis, Sytuacja prawna Tatarów hospodarskich na Litwie a zakres ich praw do ziemi (XV-XVII w.). Zarys zagadnienia, "Zeszyty Naukowe Instytutu Administracji Akademii im. Jana Długosza w Częstochowie" 2006, z. IV, s. 21-44.

5 Cz. Łapicz, Kitab Tatarów litewsko-polskich. (Paleografia. Grafia. Język), Toruń 1986, s. 29.

${ }^{6}$ A. Muchliński, Zdanie sprawy o Tatarach litewskich, przez jednego z tych Tatarów złożone sułtanowi Sulejmanowi w r. 1558. Z języka Tureckiego przełożył, objaśnił i materyałami historycznemi uzupełnił A. Muchliński, professor zwyczajny literatury Tureckiéj w Cesarskim St. Petersburskim uniwersytecie, „Teka Wileńska” 1858, nt 1 (4), Wilno, s. 260.
} 
Kryteria twórczości aljamiado spełnia także piśmiennictwo Tatarów WKL - jest realizowane w językach miejscowych: polskim i/lub białoruskim, zostało zapisane odpowiednio przystosowanym alfabetem arabskim, rozwijało się pod silnym wpływem tradycji i kultury islamu wyznawanego przez społeczność muzułmańską WKL ${ }^{7}$. Charakteryzuje się ono również cechami tylko sobie właściwymi - inną niż wyżej wymieniona literatura genezą oraz przeznaczeniem. Tatarska twórczość rękopiśmienna nie miała bowiem celu misyjnego, a służyła zachowaniu przez Tatarów, żyjących w warunkach diaspory, własnej tożsamości.

To istotnie różni ją od literatury pisanej grafią arabską na Bałkanach czy na Półwyspie Iberyjskim. Do Albanii lub innych krajów bałkańskich (Bośni, Hercegowiny) islam dotarł w wyniku ich podboju przez muzułmańską Turcję. Tam piśmiennictwo miało charakter świecki i składało się głównie z utworów lirycznych. W Hiszpanii zaś katolicyzm narzucono moryskom, tj. hiszpańskim muzułmanom, którzy po kryjomu praktykowali islam. Ich literatura obejmowała z kolei modlitewniki, traktaty religijne itd.

Twórczość litewsko-polskich muzułmanów była w znakomitej większości literaturą religijną, powstającą w warunkach dobrowolnej, niewymuszonej slawizacji i powoli postępującej chrystianizacji, co niewątpliwie przyczyniło się do dokonania przez Tatarów WKL pierwszego na świecie przekładu Koranu na język słowiański w formie tatarskiego tefsiru. Powstał on prawdopodobnie w 2. poł. XVI w., w okresie reformacji, równolegle z przekładami Biblii na języki rodzime. Jest trzecim z kolei - po łacińskim i opartym na nim tłumaczeniu włoskim - przekładem Koranu na język europejski, a zarazem pierwszym przekładem tej Księgi na język słowiański, a dokładnie na polszczyznę północnokresową ${ }^{8}$. Stanowi zatem bezcenne źródło dla opracowania spuścizny o szczególnym znaczeniu, czyli zespołu zabytków dawnej Rzeczypospolitej oraz dla prowadzenia badań w zakresie przekładu religijnych tekstów muzułmańskich na języki spoza kręgu kultury i tradycji islamu. Na formę tego tłumaczenia miały wpływ zarówno orientalna tradycja przekładowo-komentarzowa, w tym tureckie tefsiry, jak i europejska tradycja translatoryczna.

Do naszych czasów nie przetrwał jednakże typ przekładu koranicznego - polski archetyp. Znane są tylko jego późniejsze odpisy i redakcje. Do najstarszych należą: Koran z 1682 r., przechowywany w Pskowie, w którym są obecne glosy zawierające polski przekład, oraz tefsir z 1686 r. ze zbiorów Centralnej Biblioteki Naukowej Narodowej Akademii

\footnotetext{
7 Por. artykuł Cz. Łapicza, Czy piśmiennictwo Tatarów - muzułmanów Wielkiego Księstwa Litewskiego jest słowiańskim aljamiado?, [w:] W podróży za słowem: księga pamiątkowa z okazji jubileuszu 70-lecia urodzin profesora Emila Tokarza, red. M. Warchał, Bielsko-Biała 2014, s. 59-70.

8 Według Z. Kurzowej jest to „odmiana języka ogólnego, odznaczająca się zespołem innowacji w rozwoju tego języka, wytworzonych w procesie asymilacyjnym do obcego substratu językowego, upowszechnionych w obrębie zbiorowości polskiej zamieszkującej etnicznie obce terytorium białoruskie i litewskie" - Język polski Wileńszczyzny i kresów północno-wschodnich XVI-XX w., Warszawa 1993, s. 63; por. prace na temat polszczyzny północnokresowej: Z. Kurzowa, Badania nad polszczyzna kresowa w dziesięcioleciu 1973-1983, „Studia z Filologii Polskiej i Słowiańskiej" 1987, nr XXIV, s. 63-71; Z. Sawaniewska-Mochowa, Bibliografia prac o polszczyźnie kresowej, „, Studia nad Polszczyzną Kresową", t. VI, red. J. Rieger, W. Werenicz, Wrocław 1991, s. 223-254; Z. Sawaniewska-Mochowa, Bibliografia prac o polszczyźnie kresowej za lata 1989-1993 (z uzupełnieniami do roku 1988), "Studia nad Polszczyzną Kresową", t. VIII, red. J. Rieger, Wrocław 1995, s. 265-282; A. Pihan-Kijasowa, Literacka polszczyzna kresów północno-wschodnich XVII wieku. Fonetyka, Poznań 1999; K. Handke, Terytorialne odmiany polszczyzny, [w:] Współczesny język polski, red. J. Bartmiński, Lublin 2001, s. 201-219; Z. Sawaniewska-Mochowa, Bibliografia "kowieńska" [układ działowy: prace językoznawcze (poz. 1-87), prace niejęzykoznawcze (poz. 88-150), literatura popularna (poz. 151-173)], [w:] Nazwy mówiq, red. M. Pająkowska-Kensik, M. Czachorowska, Bydgoszcz 2004, S. 203-220; Z. Kurzowa, Ze studiów nad polszczyzna kresowq, Kraków 2007; J. Mędelska, Z. Sawaniewska-Mochowa, Językowe i kulturowe dziedzictwo Wielkiego Księstwa Litewskiego. Księga jubileuszowa na 1000-lecie Litwy, Bydgoszcz 2010.
} 
Nauk Białorusi w Mińsku. Tatarscy translatorzy tłumaczyli z języka arabskiego, posiłkując się przekładami tureckimi lub bezpośrednio z tureckiego (por. rolę tłumaczeń łacińskich i czeskich w polskiej tradycji psałterzowej i biblijnej). Pierwszy przekład Koranu (według dostępnych źródel) był oparty na Tafsirze at-Tabariego i dokonany w języku perskim za czasów Mansura I (X w.), który powołał grupę specjalistów-uczonych w celu sporządzenia najbardziej prawowiernego tłumaczenia. Mniej więcej w tym samym czasie przełożono Koran na staroturecki. Tłumaczenia Koranu na język turecki dokonywano w celach misyjnych (islamizacja plemion tureckich na obszarze Azji Środkowej i wschodniego Turkiestanu pod wpływem państwa Samanidów ze stolicą w Bucharze) - nie bezpośrednio z arabskiego, ale z perskiego.

Tradycja powstawania podwierszowych przekładów w Średniej Azji miała swój początek prawdopodobnie w XI w., a była kontynuowana do XV stulecia w Anatolii (język osmańsko-turecki) - przypuszcza się, że stamtąd przejęli ją Tatarzy WKL ${ }^{9}$.

Przyczynkiem do stwierdzenia, czy przekładu koranicznego tekstu dokonano wprost $\mathrm{z}$ oryginału arabskiego, czy może tłumaczono z tureckiego, czy też posiłkowano się wzorcem tureckim jest m.in. ustalenie zależności między tatarskimi i tureckimi tefsirami.

Do charakterystycznych cech tureckich tefsirów, dla których można by zbudować analogie z tymi tatarskimi należą:

- dostępność kopii, pochodzących z wieków od XIV do XVI, konserwujących archaiczne cechy językowe XII- i XIII-wieczne;

- mieszanie się cech językowych charakterystycznych dla różnych dialektów. Dostępne badaczom tefsiry są niejednorodne - można w nich zidentyfikować cechy gramatyczne i leksykalne typowe dla różnych grup języków tureckich - język Oguzów, ujgurski, dialekty karlukskie, kipczackie;

- dosłowność przekładu;

- liczne błędy kopistów, wynikające z nieznajomości m.in. gramatyki języka staroarabskiego $^{10}$.

Natomiast niewątpliwie ważną cechą tatarskich tefsirów, różniącą je od tureckich zabytków tego typu jest hetrogeniczność przekładu - można w nich bowiem odnaleźć wykładniki przekładu dosłownego i swobodnego.

W celu stwierdzenia, czy tureckie tefsiry były podstawą tłumaczenia dla Tatarów, należałoby zbadać:

- technikę przekładu,

- stopień pokrewieństwa,

- powtarzanie tych samych błędów,

- wpływy na tłumaczenie sekt muzułmańskich - szyitów lub sunnitów,

- obecność źródeł tureckojęzycznych.

Na powstanie tatarskich tefsirów miała również wpływ biblijna tradycja przekładowa. Tatarzy korzystali bowiem z wcześniej wypracowanych metod przekładu ksiąg sakralnych na języki narodowe, począwszy od wyboru typu przekładu poprzez konkretne rozwiązania

9 Х. И. Уста, Исторический обзор первых подстрочных переводов корана (на материале тюрских языков), [w:] Tiurku Istorija ir Kultūra Lietuvoje. Turks' History and Culture in Lithuania. История и Культура Тюрков в Литве, red. T. Bairašauskaitè, G. Miškinienè, Vilnius 2014, s. 162.

10 Ibidem, s. 157-161. 
translatorskie, a skończywszy na adaptacji staropolskiej leksyki, zwłaszcza religijnej, do pojęć i terminologii islamu.

Cechą charakterystyczną muzułmańskich tłumaczeń jest przy tym - uzasadnione otoczeniem chrześcijańskim - odwoływanie się do staropolskiej literatury biblijno-psatterzowej oraz do polskich przekładów Pisma św., polegające m.in. na posiłkowaniu się nimi w translacji islamskich tekstów źródłowych. Badania w tym zakresie są prowadzone w dwóch kierunkach: wykorzystywania w procesie przekładu wzorca, jakim jest chrześcijańska tradycja tłumaczeniowa, oraz włączanie do muzułmańskiego piśmiennictwa religijnego odpowiednio zmodyfikowanych źródeł chrześcijańskich.

Problem filologiczny stanowi ustalenie konkretnego przekładu biblijnego, na którym opierali się Tatarzy WKL. Wiadomo, iż szeroko wykorzystywali przekłady innowiercze Biblię brzeską i Biblię nieświeską, których translatorzy reprezentowali zbieżne z litewsko-polskimi muzułmanami poglądy na tak istotne kwestie, jak np. dogmat o Trójcy Świętej, bóstwo Jezusa Chrystusa, powszechne kapłaństwo. W szczególności czerpali zatem z literatury kręgu chrześcijaństwa reformacyjnego, a dokładnie z religijnego piśmiennictwa ariańskiego.

Ponadto badacze wskazują na obecność w tatarskich manuskryptach, m.in. Historyi barzo cudnej... Krzysztofa Pussmana z 1543 r. ${ }^{11}$, Psalmów w przekładzie Jana Kochanowskiego $^{12}$, Psalmów w przekładzie biskupa Ignacego Krasickiego ${ }^{13}$, fragmentów tragikomedii Giovanniego Battisty Guarniego, Pastor Fido, albo Konterfekt Wierny Miłości, także w przekładzie Ignacego Krasickiego ${ }^{14}$, Legendy o św. Hiobie ${ }^{15}$, Legendy o św. Grzegorzu ${ }^{16}$ oraz innych źródeł z chrześcijańskiego kręgu kulturowego, w tym nawet katolickiej Biblii w tłumaczeniu Jakuba Wujka.

Podkreśla się zarazem, iż Tatarzy nie zawsze korzystali z oryginalnych źródeł, które da się bezbłędnie zidentyfikować, albowiem znaczna ich część wskazuje na czerpanie z polemik i dysput religijnych, przytaczanie z pamięci, kompilowanie itd. Ponadto wykorzystywane przez siebie źródła zawsze adaptowali do potrzeb wyznawanego przez nich islamu. Artur Konopacki stawia tezę, iż funkcjonowało teologiczne piśmiennictwo Tatarów, polegające na komponowaniu własnych dzieł na podstawie religijnych tekstów chrześcijańskich poprzez chociażby usuwanie treści niezgodnych $\mathrm{z}$ islamem ${ }^{17}$, a więc, np. eliminowanie lub przekształcanie cytatów niezgodnych z doktryną tej religii, czyli mówiących o bóstwie Jezusa, o Trójcy Św., o tym, kogo zaliczyć do potomstwa Abrahama - Izaaka czy Izmaela?, o osobie Ducha Św. itd. Jak się okazuje, kompilacje licznych tekstów źródłowych, ich modyfikacje, poszerzanie o kolejne materiały źródłowe stanowią o istocie tekstów apokryficz-

11 M. Adamczyk, Biblijno-apokryficzne narracje w literaturze staropolskiej do końca XVI wieku, Poznań 1980; A. Drozd, Staropolski apokryf w muzułmańskich księgach. (Tatarska adaptacja Historyji barzo cudnej o stworzeniu nieba i ziemie Krzysztofa Pussmana), „Poznańskie Studia Polonistyczne” 1996, t. 3 (23), Seria Literacka, s. 95-134.

12 M. Tarełka, I. Synkowa, Adkul pajszli idały, Mińsk 2009.

13 I. Radziszewska, Chamaiły jako typ piśmiennictwa religijnego muzułmanów Wielkiego Księstwa Litewskiego (na podstawie słowiańskiej warstwy językowej), praca doktorska, Uniwersytet Mikołaja Kopernika, Toruń 2010 (komputeropis).

14 Ibidem.

15 A. Drozd, Tatarska wersja pieśni-legendy o św. Hiobie, „Poznańskie Studia Polonistyczne” 1995a, t. 2 (22), Seria Literacka, s. 163-195.

16 K. Dufala, Legenda o św. Grzegorzu w kitabie Tatarów - muzułmanów Wielkiego Księstwa Litewskiego, [w:] Chrestomatia teolingwistyki, red. A. Gadomski, Cz. Łapicz, Symferopol 2008-2009, s. 205-220.

17 A. Konopacki, Życie religijne Tatarów na ziemiach Wielkiego Księstwa Litewskiego w XVI-XIX wieku, Warszawa 2010, s. 155. 
nych, albowiem ich specyficzną cechą jest „bycie w ciągłym ruchu, ciągłej przemianie, co $\mathrm{w}$ efekcie prowadzi do wykształcenia struktur stanowiących swego rodzaju uzupełnienie uzupełniania"18.

Na przykładzie związków tatarskich tłumaczeń z europejską tradycją przekładową można zatem wykazać zarówno przenikanie kultur, jak i cechy służące utrzymaniu kulturowej odrębności oraz tożsamości Tatarów WKL.

Mimo wielu zbieżności z translacjami biblijnymi - tatarskie teksty przekładowe charakteryzują się także wysokim stopniem oryginalności i zachowaniem własnej autonomii, np. w zakresie przyjętych sposobów i metod przekładu - nie da się ich jednoznacznie zaklasyfikować jako werbalnych lub swobodnych. O próbie zachowania autonomiczności świadczy również twórcza adaptacja terminologii chrześcijańskiej do kanonów i zasad wiary muzułmańskiej. Przekłady tatarskie cechuje również wysoki stopień frekwencji terminów translokowanych bądź slawizowanych. Translatorzy mieli bowiem pełną świadomość nieprzekładalności specjalistycznej terminologii muzułmańskiej na języki słowiańskie. Tak więc terminy religijne obcego pochodzenia często pozostawiali nieprzetłumaczone, z jednej strony ze względu na brak adekwatnych odpowiedników w językach słowiańskich, z drugiej przyjmowali zaś, iż powinny być one zrozumiałe dla praktykujących muzułmanów. Zachowywali zatem w oryginalnej formie terminy istotne z punktu widzenia doktryny oraz takie, które były właściwe tylko religii muzułmańskiej, a zwłaszcza nazwy własne. Jeden $\mathrm{z}$ badaczy tatarskiego piśmiennictwa religijnego stwierdził, iz „70 z nich odnosi się do centralnych pojęć religii islamu"19.

\section{Filomaci - ks. Dionizy Chlewiński i Ignacy Domeyko - autorami „chrześcijańskiego tłumaczenia Koranu”}

Pierwszy drukowany przekład Koranu na język polski ukazał się w Warszawie w $1858 \mathrm{r}$. sygnowany nazwiskiem polskiego Tatara Jana Murzy Tarak Buczackiego. W rzeczywistości autorami tłumaczenia byli dwaj wileńscy filomaci ks. Dionizy Chlewiński ${ }^{20}$ i Ignacy Domeyko $^{21}$. Co interesujące - jeden z nich to ksiądz katolicki, w przypadku drugiego w 2008 r. rozpoczęto proces beatyfikacyjny. Ignacy Domeyko to bowiem wybitny polski uczony, geolog, badacz Ameryki Południowej i bohater III części Dziadów Adama Mickiewicza, noszący pseudonim Żegota. Jak się okazuje, Domeyko działał nie tylko w środowisku polskich Tatarów, przyczyniając się do budowania ich tożsamości poprzez przekład najważniejszej dla ich wiary Księgi, ale swoje przetrwanie zawdzięczają mu również

18 T. Mika, W. Twardzik, Jak zagadkowe cztery tytuły rozdziałów w "Rozmyślaniu przemyskim” pozwalaja wyobrażać sobie jego zagubiony autograf, ,Język Polski" 2011, XCl, z. 5, s. 323.

19 P. Suter, Alfurkan Tatarski. Der litauisch-tatarische Koran-Tefsir, Köln-Weimar-Wien 2004, s. 57-61.

20 T. Krahel, Archidiecezja wileńska w latach II wojny światowej: studia i szkice, Seria Wydawnicza Oddziału Instytutu Pamięci Narodowej w Białymstoku, t. 23, 2014.

21 Z. J. Ryn, Ignacy Domeyko. Kalendarium życia, Kraków 2006. 
Indianie Mapuche - chilijskie plemię (dziś ok. miliona osób), któremu poświęcił pracę Araukania i jej mieszkańcy. Polak - wysłany w asyście wojskowej na ziemie Mapuchów przez ówczesnego prezydenta Chile - opisał w niej życie i kulturę plemienia. To właśnie dzięki tej książce - wielokrotnie wznawianej - prezydent podjął decyzję, by zmienić dotychczasową politykę eksterminacji Mapuchów na ich asymilację. Domeyko doprowadził tym samym do ocalenia tej indiańskiej populacji.

W 1. poł. XIX w. wpływy Wilna i Cesarskiego Uniwersytetu Wileńskiego promieniowały na cały kraj. Wilno stanowiło centrum rozwoju polskiego szkolnictwa, było stolicą polskiego romantyzmu i znaczącym ośrodkiem polskiej kultury, łącznie z rozkwitem badań orientalistycznych. Stąd dla badaczy piśmiennictwa Tatarów - muzułmanów WKL niezwykle ważna była wiadomość o odkryciu fragmentu nieznanego rękopisu polskiego przekładu Koranu, pochodzącego prawdopodobnie z 1. poł. XIX stulecia ${ }^{22}$. Wstępne ustalenia dotyczące autorstwa, miejsca i czasu sporządzenia rękopisu znalazły potwierdzenie w późniejszych szczegółowych badaniach tekstologicznych i filologicznych, zwłaszcza grafii, ortografii oraz języka tekstu, a także papieru opatrzonego filigranem z widocznym rokiem produkcji: 1821 . W trakcie prac eksperckich nad rękopisem ukazały się dwie publikacje o tym zabytku, które z dużym prawdopodobieństwem wyjaśniły okoliczności ocalenia i odnalezienia manuskryptu ${ }^{23}$, będącego oryginalnym źródłem do dziejów przekładu literatury religijnej Tatarów WKL, a zarazem do dziejów polszczyzny północnokresowej. Okazało się, że rękopis znajdował się w zbiorach dworskiego archiwum w Czombrowie (warto dodać, że Czombrów jest dziś uznawany za pierwowzór mickiewiczowskiego Soplicowa), uratowanych z wojennej zawieruchy (dwór w Czombrowie w czasie działań wojennych został spalony przez Sowietów) i przewiezionych do Warszawy przez ostatnich właścicieli majątku. Prawdopodobnie tłumaczenie Koranu zostało im przekazane przez samych filomatów. Dwór w Czombrowie - obok Worończy - był bowiem jednym z najznakomitszych w tej okolicy, i jako taki stanowił miejsce spotkań literatów, w tym także filomatów i filaretów oraz muzyków, poetów itp., co w poł. XIX w. miało znaczenie polityczne i wymiar patriotyczny.

Zatem autorem pierwszego drukowanego przekładu Koranu na język polski nie był Jan Buczacki, lecz dokonali go dwaj filomaci wileńscy, którzy po ukończeniu pracy translatorskiej podjęli w carskiej cenzurze w Wilnie starania o pozwolenie na druk ${ }^{24}$. Spotkała

${ }^{22} \mathrm{~W}$ prezentowanym artykule podano najistotniejsze informacje na temat niedawno odkrytego rękopisu filomackiego przekładu Koranu - odwołując się m.in. do opracowania: A. Konopacki, J. Kulwicka-Kamińska, Cz. Łapicz, Nieznany rękopis polskiego przekładu Koranu, ",Colloquia Orientalia Bialostocensia”, Estetyczne aspekty literatury polskich, białoruskich i litewskich Tatarów (od XVI do XXI w.) / Aesthetic Aspects of the Literature of Polish, Belarusian and Lithuanian Tatars (XVIth-XXIst century) / Эстетические аспекты литературы польских, белорусских и литовских татар (XVI-XXI вв.), red. G. Czerwiński, A. Konopacki, Białystok 2015, s. 49-67.

23 J. Puchalska, Koran w Soplicowie. Tajemnicza historia pewnego manuskryptu , Ż̇ycie Tatarskie" 2014, styczeń-czerwiec, nr 39 (116), s. 99-105, oraz eadem, Dziedziczki Soplicowa, Warszawa 2014.

24 Por. ustalenia dotyczące relacji pomiędzy rzeczywistymi translatorami a środowiskiem tatarskim oraz na temat autorstwa przekładu Koranu z 1858 r.: B. Baranowski, Znajomość Orientu w dawnej Polsce , „Sprawozdania z Czynności i Posiedzeń Łódzkiego Towarzystwa Naukowego" 1949, (III) nr 1 [5]; J. Reychman, Próba organizacji orientalizmu polskiego doby Mickiewicza , Przegląd Orientalistyczny" 1954, nr 2; A. Zajączkowski, Orient jako źródło inspiracji w literaturze doby mickiewiczowskiej, Warszawa 1955; J. Reychman, Zainteresowania orientalistyczne wśrodowisku mickiewiczowskim w Wilnie iPetersburgu, [w:] Szkicezdziejówpolskiejorientalistyki, t. 1, red.S. Strelcyn, Warszawa 1957; J. Reychman, Orient w kulturze polskiego oświecenia, Warszawa 1964; Z. Wójcik, Filomacki przekład Alkoranu dla Tatarów nowogródzkich, "Literatura Ludowa” 1995, XXXIX, nr 3, s. 15-28; T. Bairašauskaite, Lietuvos totoriai XIX am iuje, Vilnius 1996; A. Drozd, W sprawie autorstwa Koranu Buczackiego, [w:] Z Mekki do Poznania, red. H. Jankowski, Poznań 1998, s. 69-83; J. Kulwicka-Kamińska, Kształtowanie się polskiej terminologii islamisty- 
ich odmowa urzędu cenzorskiego m.in. ze względu na to, że obaj byli skazani w procesie filomatów i nazwiska ich widniały w kartotekach carskiej policji. Przekazali więc rękopis swego dzieła Tatarom, by to oni zabiegali o druk - tak ważnego dla polskich wyznawców islamu - tekstu. Prośbę w tej sprawie złożył u cara Mikołaja I w Sankt-Petersburgu Tatar i muzułmanin, imam Józef Sobolewski. Podał się on przy tym - zapewne za wiedzą i zgodą rzeczywistych translatorów - za autora przekładu Koranu z języka rosyjskiego. Jednak car również odmówił zgody na jego publikację.

Przez kilkanaście kolejnych lat (1830-1848) przekład pozostawał w rękopisie bez nadziei na druk. Jednak w 1848 r. (?) działania wydawnicze podjął w Poznaniu Bernard Potocki. Przerwano go jednak, a wydawca zniszczył nakład z wyjątkiem ocalałego fragmentu liczącego 11 pierwszych (a więc najdłuższych) sur.

Podejmując kilkakrotnie starania o zgodę na publikację przekładu, najpierw jego autorzy w cenzurze wileńskiej, później Tatarzy w kancelarii carskiej, w wydawnictwie poznańskim oraz w cenzurze warszawskiej i w wydawnictwie Nowoleckiego - niewątpliwie musieli składać rękopisy (czystopisy) ukończonego dzieła. Trzeba przyjąć, że powstało co najmniej kilka kopii tłumaczenia, choć niekoniecznie sporządzali je sami translatorzy. Kopiowanie tekstów religijnych mieściło się w tradycji i praktyce piśmienniczej Tatarów WKL, którzy przez stulecia (od XVI w.) w ten sposób sporządzali swoje tefsiry, kitaby, chamaity oraz inne księgi czy pisma użytkowe. Z pewnością sporządzono również jakąś liczbę kopii przekładu filomatów, które nie tylko zostały złożone w urzędach cenzorskich oraz oficynach wydawniczych, ale pozostały też $\mathrm{w}$ domowych archiwach bądź samych kopistów, bądź osób zainteresowanych ich posiadaniem. Można przypuszczać, że rękopis taki posiadał Tatar Józef Sobolewski, który składał petycję do cara w sprawie druku przekładu, a nieco później cytował go we własnej publikacji z $1830 \mathrm{r}^{25}$ Rękopisem przekładu musiał również dysponować wydawca poznański, Bernard Potocki, który rozpoczął jego druk. Nie zachowały się jednak ani oryginalny rękopis Chlewińskiego i Domeyki, ani jego kopie. Cała wiedza o filomackiej wersji przekładu pochodzi z nieadiustowanego fragmentu edycji poznańskiej oraz z opracowanej redakcyjnie, a zatem w porównaniu z oryginalnym rękopisem znacznie zmienionej, wersji warszawskiej, która ukazała się pod nazwiskiem Jana Buczackiego.

Zachowany fragment przekładu filomatów $\mathrm{z}$ edycji poznańskiej obejmuje 10 pierwszych, czyli najdłuższych (z wyjątkiem sury pierwszej), sur Koranu oraz 86 ajatów sury jedenastej. W sumie fragment ten liczy 1558 ajatów. W przybliżeniu jest to około $25 \%$ całkowitej liczby koranicznych wersetów ${ }^{26}$. Odnaleziony rę-

cznej, Toruń 2001 (komputeropis pracy doktorskiej), s. 35-40; Cz. Łapicz, Chrześcijańsko-muzułmańska interferencja religijna w rękopisach Tatarów Wielkiego Księstwa Litewskiego, [w:] Lietuvos Didžiosios Kunigaikštystes kalbos, kultūros ir raštijos tradicijos, Vilnius 2009, s. 303; Cz. Łapicz, Z teorii i praktyki przekładów Koranu (wybrane zagadnienia), [w:] Chrestomatia teolingwistyki, s. 269-288; Cz. Łapicz, Niezwykłe losy pierwszego drukowanego przekładu Koranu na język polski, „Poznańskie Studia Polonistyczne” 2013, Seria Językoznawcza, t. 20 (40), z. 2, s. 129-143; Cz. Łapicz, Spór o autorstwo polskiego przekładu Koranu z 1858 roku, [w:] Dialog chrześcijańsko-muzułmański: teoria, praktyka, perspektywy, red. M. Lewicka, Cz. Łapicz, Toruń 2013, s. 245-260; J. Kulwicka-Kamińska, Przekład terminologii religijnej islamu w polskich tłumaczeniach Koranu na tle biblijnej tradycji translatorycznej, Toruń 2013, s. 75. Historię przekładów Koranu na język polski, z podaniem literatury przedmiotu w tym zakresie, szczegółowo omówiono także w pracy J. Kulwickiej-Kamińskiej, Kształtowanie się polskiej terminologii muzułmańskiej, Toruń 2004.

25 Por. Cz. Łapicz, Źródła cytatów koranicznych w Wykładzie wiary machometańskiej, czyli iślamskiej... Józefa Sobolewskiego z 1830 r., [w:] Tatarzy Wielkiego Księstwa Litewskiego w historii, języku i kulturze, red. J. KulwickaKamińska, Cz. Łapicz, Toruń 2013, s. 185-202.

${ }_{26}$ Na podstawie kserokopii poznańskiej edycji Koranu filomatów, sporządzonej z oryginału przechowywanego w Bibliotece PAN w Kórniku. 
kopis z Czombrowa zawiera 26 sur, jednak w sumie liczą one 351 ajatów, tzn. ponad 5\% pełnej objętości Księgi. Wynika to z faktu, iż ten fragment rękopisu obejmuje sury końcowe, a więc najkrótsze. Opisywany rękopis zawiera więc sury LXIX-LXXI oraz od LXXXIX do CXI.

W zbiorach Państwowego Muzeum Historii Religii w Grodnie (Białoruś) jest przechowywany arabski rękopis identyfikowany w muzealnym katalogu jako Koran. Bliższy ogląd formy i treści zabytku pozwala stwierdzić, iż zawiera on polski przekład Koranu zapisany alfabetem arabskim. Rękopis z Muzeum Historii Religii w Grodnie ma dokładnie taką formę, jak tradycyjne tefsiry Tatarów - muzułmanów WKL. Jednak odczytanie umieszczonego interlinearnie polskiego tekstu pozwala stwierdzić, że zawiera on zapisaną w formie tefsirowej transliterację z alfabetu łacińskiego na arabski polskiego przekładu Koranu z 1858 r. (edycja warszawska), sygnowanego nazwiskiem Jana Murzy Tarak Buczackiego, faktycznie będącego wersją przekładu wykonanego 30 lat wcześniej (ok. 1828 r.) przez wileńskich filomatów. Tym samym pierwszemu drukowanemu polskiemu przekładowi Koranu, będącemu faktycznie dziełem wileńskich filomatów, wtórnie nadano status i rękopiśmienną formę tefsiru. Tak więc przekład powstał w końcu lat 20. XIX w., jednak do odnalezienia rękopisu z Czombrowa nie był znany choćby jego najmniejszy oryginalny fragment. Edycja poznańska ma formę drukarskiej szczotki, natomiast edycja warszawska została opracowana edytorsko, opatrzona przypisami i komentarzami, dlatego odbiega od rękopiśmiennego oryginału filomackiego. Edycja warszawska została ponadto przekształcona w tefsir zgodny z egzegetyką islamu oraz z tradycją piśmiennictwa muzułmanów WKL.

\section{Podsumowanie}

Wielkie Księstwo Litewskie jest w dziejach Europy unikalnym przykładem pokojowej koegzystencji wielu narodowości, kultur i religii. Od XIV w. swoje losy związali z ziemiami Księstwa tatarscy osadnicy, reprezentujący typ kultury inkluzywnej - otwartej na zewnętrzne wpływy. Pełna asymilacja $\mathrm{z}$ chrześcijańskim otoczeniem znalazła wyraz w materialnym i niematerialnym dziedzictwie kulturowym tej grupy etnicznej, do którego należą zarówno obiekty architektoniczne, jak i osobliwa literatura religijna, w tym pierwszy w Europie przekład Koranu na języki słowiańskie. Bezpośrednią implikacją panującej w dawnej Rzeczypospolitej tolerancji kulturowej była również współpraca katolików (filomatów wileńskich) i muzułmanów (Tatarów WKL) w zakresie tłumaczenia i wydania XIX-wiecznej translacji świętej Księgi islamu.

Szczegółową charakterystykę wzajemnych relacji i wpływów między Polską a krajami Orientu w dobie nowopolskiej, a zwłaszcza w XVIII i XIX w. przynoszą prace historyków, literaturoznawców, orientalistów i slawistów ${ }^{27}$. Według Jana Reychmana epoka oświecenia ukazała nowe oblicze Turcji jako baśniowej, egzotycznej krainy, interesującej dla literatów i filozofów encyklopedyzmu ${ }^{28}$. Zainteresowania te rozwinęły się jeszcze bardziej w epokach

27 Por. opracowanie tego zagadnienia wraz z bibliografią - J. Kulwicka-Kamińska, Kształtowanie się polskiej terminologii islamistycznej, Toruń 2001 (komputeropis pracy doktorskiej), s. 17-20 oraz s. 261-263.

28 J. Reychman, Historia Turcji, Wrocław 1973, s. 171. 
romantyzmu, pozytywizmu i Młodej Polski, co wiązało się z zapoczątkowaną już w XVIII w. modą na orientalizm we wszystkich dziedzinach kultury, a także w zakresie obyczajów, życia towarzyskiego, podawanych potraw.

Początek XIX stulecia przyniósł rozwój studiów orientalistycznych. W środowisku profesorów Uniwersytetu Wileńskiego zrodziło się głębsze zainteresowanie dla literatury orientalnej. Tu miała swój początek polska orientalistyka uniwersytecka (Ernest Gotfryd Groddeck, Józef Julian Sękowski, Jan Nepomucen Wiernikowski, Michał Bobrowski, Józef Kowalewski, Aleksander Borejko Chodźko, Ludwik Spitznagel). Środowisko wileńskie doby mickiewiczowskiej przyniosło także pierwsze w literaturze polskiej próby wskazania na piśmiennictwo orientalne oraz pierwsze przekłady z oryginałów w językach orientalnych. Kontynuacją tego nurtu były wczesnopozytywistyczne dyrektywy, zawarte w publicystyce programowej (np. Piotr Chmielowski, Geniusze i masy) oraz postulaty pisarzy i publicystów 2. poł. XIX w., aby tłumaczyć na język polski arcydzieła piśmiennictwa Orientu. Wówczas wprost zachęcano do „penetracji (popularnonaukowych i naukowych) kultur odległych”, $\mathrm{w}$ tym popularyzowania piśmiennictwa Wschodu ${ }^{29}$. Mimo to istotnym wyróżnikiem recepcji Orientu w 2. poł. XIX w. jest stosunkowo skromny dorobek przekładowy (zwłaszcza $\mathrm{w}$ zakresie tłumaczeń z oryginału) ${ }^{30}$. Tym bardziej należy docenić pionierską pracę polskich filomatów z 1. poł. XIX w., stanowiącą bezcenne źródło do badania pograniczy kultury polskiej.

\section{Bibliografia}

Adamczyk Maria, Biblijno-apokryficzne narracje w literaturze staropolskiej do końca XVI wieku, Poznań: Wydawnictwo Naukowe UAM, 1980.

Baranowski Bohdan, Znajomość Orientu w dawnej Polsce, „Sprawozdania z Czynności i Posiedzeń Łódzkiego Towarzystwa Naukowego" 1949, (III) nr 1 [5].

Bairašauskaite Tamara, Lietuvos totoriai XIX am ،iuje, Vilnius: Mintis, 1996.

Drozd Andrzej, Tatarska wersja pieśni-legendy o św. Hiobie, „Poznańskie Studia Polonistyczne” 1995, t. 2 (22).

Drozd Andrzej, Staropolski apokryf w muzutmańskich ksiegach. (Tatarska adaptacja Historyji barzo cudnej o stworzeniu nieba i ziemie Krzysztofa Pussmana), „Poznańskie Studia Polonistyczne” 1996, t. 3 (23).

Drozd Andrzej, Wsprawie autorstwa Koranu Buczackiego, [w: ] ZMekki do Poznania, red. H.Jankowski, Poznań: Katedra Orientalistyki i Bałtologii, Uniwersytet im. Adama Mickiewicza, 1998.

Dufala Krystyna, Legenda o św. Grzegorzu w kitabie Tatarów - muzulmanów Wielkiego Księstwa Litewskiego, [w:] Chrestomatia teolingwistyki, red. A. Gadomski, Cz. Łapicz, Symferopol: Universum, 2008-2009.

Grygajtis Krzysztof, Sytuacja prawna Tatarów hospodarskich na Litwie a zakres ich praw do ziemi (XV-XVII w.). Zarys zagadnienia, „Zeszyty Naukowe Instytutu Administracji Akademii im. Jana Długosza w Częstochowie" 2006, z. IV.

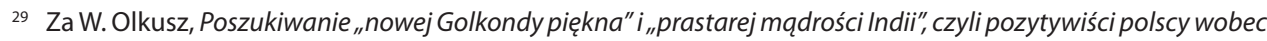
kultury Orientu, Opole 1992, s. 139.

30 Ibidem, s. 140. 
Handke Kwiryna, Terytorialne odmiany polszczyzny, [w:] Wspótczesny język polski, red. J. Bartmiński, Lublin: „Wiedza o kulturze”, 2001.

Konopacki Artur, Życie religijne Tatarów na ziemiach Wielkiego Księstwa Litewskiego w XVI-XIX wie$k u$, Warszawa: Wydawnictwa Uniwersytetu Warszawskiego, 2010.

Konopacki Artur, Kulwicka-Kamińska Joanna, Łapicz Czesław, Nieznany rękopis polskiego przekładu Koranu, „Colloquia Orientalia Bialostocensia”, Estetyczne aspekty literatury polskich, biatoruskich i litewskich Tatarów (od XVI do XXI w.), red. G. Czerwiński, A. Konopacki, Białystok: Alter Studio, 2015.

Krahel Tadeusz, Archidiecezja wileńska w latach II wojny światowej: studia i szkice, Seria Wydawnicza Oddziału Instytutu Pamięci Narodowej w Białymstoku, t. 23, 2014.

Kryczyński Stanisław, Zygmunt August a Tatarzy litewscy, „Przegląd Islamski” 1934, z. $3 / 4$.

Kulwicka-Kamińska Joanna, Ksztaltowanie się polskiej terminologii islamistycznej, Toruń 2001 (komputeropis pracy doktorskiej).

Kulwicka-Kamińska Joanna, Ksztattowanie się polskiej terminologii muzułmańskiej, Toruń: Towarzystwo Naukowe w Toruniu, 2004.

Kulwicka-Kamińska Joanna, Przekład terminologii religijnej islamu w polskich ttumaczeniach Koranu na tle biblijnej tradycji translatorycznej, Toruń: Wydawnictwo Naukowe UMK, 2013.

Kurzowa Zofia, Język polski Wileńszczyzny i kresów pótnocno-wschodnich XVI-XX w., Warszawa: Wydawnictwo Naukowe PWN, 1993.

Kurzowa Zofia, Badania nad polszczyzna kresowa w dziesięcioleciu 1973-1983, „Studia z Filologii Polskiej i Słowiańskiej” 1987, nr XXIV.

Kurzowa Zofia, Ze studiów nad polszczyzna kresowa, Kraków: Universitas, 2007.

Łapicz Czesław, Kitab Tatarów litewsko-polskich. (Paleografia. Grafia. Język), Toruń: Wydawnictwo UMK, 1986.

Łapicz Czesław, Chrześcijańsko-muzutmańska interferencja religijna w rękopisach Tatarów Wielkiego Księstwa Litewskiego, [w: Lietuvos Didžiosios Kunigaikštystes kalbos, kultūros ir raštijos tradicijos, Bibliotheca Archivi Lithuanici 7, Vilnius 2009.

Łapicz Czesław, $Z$ teorii i praktyki przekładów Koranu (wybrane zagadnienia), [w:] Chrestomatia teolingwistyki, red. A. Gadomski, Cz. Łapicz, Symferopol: Universum, 2008-2009.

Łapicz Czesław, Niezwykłe losy pierwszego drukowanego przekładu Koranu na język polski, „Poznańskie Studia Polonistyczne” 2013, Seria Językoznawcza, t. 20 (40), z. 2, Wydawnictwo Poznańskiego Towarzystwa Przyjaciół Nauk.

Łapicz Czesław, Spór o autorstwo polskiego przekładu Koranu z 1858 roku, [w: Dialog chrześcijańsko-muzutmański: teoria, praktyka, perspektywy, red. M. Lewicka, Cz. Łapicz, Toruń: Wydawnictwo Naukowe UMK, 2013.

Łapicz Czesław, Źródła cytatów koranicznych w Wykładzie wiary machometańskiej, czyli iślamskiej... Józefa Sobolewskiego z 1830 r., [w:] Tatarzy Wielkiego Księstwa Litewskiego w historii, języku i kulturze, red. J. Kulwicka-Kamińska, Cz. Łapicz, Toruń: Towarzystwo Naukowe w Toruniu, 2013.

Łapicz Czesław, Czy piśmiennictwo Tatarów - muzułmanów Wielkiego Księstwa Litewskiego jest stowiańskim aljamiado?, [w:] W podróży za słowem: księga pamiątkowa $z$ okazji jubileuszu 70-lecia urodzin profesora Emila Tokarza, red. M. Warchał, Bielsko-Biała: Wydawnictwo Naukowe Akademii Techniczno-Humanistycznej, 2014.

Martin Walter, Świat religii i sekt, Warszawa: Chrześcijański Instytut Biblijny, 2004.

Mędelska Jolanta, Sawaniewska-Mochowa Zofia, Językowe i kulturowe dziedzictwo Wielkiego Księstwa Litewskiego. Księga jubileuszowa na 1000-lecie Litwy, Bydgoszcz: Uniwersytet Kazimierza Wielkiego, 2010.

Mika Tomasz, Twardzik Wacław, Jak zagadkowe cztery tytuly rozdziałów w „Rozmyślaniu przemyskim” pozwalają wyobrażać sobie jego zagubiony autograf, „Język Polski” 2011, XCI, z. 5 
Muchliński Antoni, Zdanie sprawy o Tatarach litewskich, przez jednego z tych Tatarów złożone sultanowi Sulejmanowi w r. 1558. Z języka Tureckiego przetożyt, objaśnit i materyałami historycznemi uzupetnit A. Muchliński, professor zwyczajny literatury Tureckiéj w Cesarskim St. Petersburskim uniwersytecie, „Teka Wileńska” 1858, nr 1 (4).

Olkusz Wiesław, Poszukiwanie "nowej Golkondy piękna” i „prastarej mądrości Indii”, czyli pozytywiści polscy wobec kultury Orientu, Opole: Wyższa Szkoła Pedagogiczna im. Powstańców Śląskich, 1992.

Pihan-Kijasowa Alicja, Literacka polszczyzna kresów pótnocno-wschodnich XVII wieku. Fonetyka, Poznań: Wydawnictwo Naukowe UAM, 1999.

Puchalska Joanna, Koran $w$ Soplicowie. Tajemnicza historia pewnego manuskryptu, „Życie Tatarskie” 2014, nr 39 (116).

Puchalska Joanna, Dziedziczki Soplicowa, Warszawa: MUZA SA, 2014.

Radziszewska Iwona, Chamaity jako typ piśmiennictwa religijnego muzutmanów Wielkiego Księstwa Litewskiego (na podstawie stowiańskiej warstwy językowej), praca doktorska, Uniwersytet Mikołaja Kopernika, Toruń 2010 (komputeropis).

Reychman Jan, Próba organizacji orientalizmu polskiego doby Mickiewicza, „Przegląd Orientalistyczny” 1954, nr 2.

Reychman Jan, Zainteresowania orientalistyczne w środowisku mickiewiczowskim w Wilnie i Petersburgu, [w:] Szkice z dziejów polskiej orientalistyki, t. 1, red. S. Strelcyn, Warszawa 1957.

Reychman Jan, Orient w kulturze polskiego oświecenia, Warszawa: Ossolineum, 1964.

Reychman Jan, Historia Turcji, Wrocław: Zakład Narodowy im. Ossolińskich, 1973.

Ryn Zdzisław Jan, Ignacy Domeyko. Kalendarium życia, Kraków: Wydawnictwo PAU, UJ, AGH, 2006.

Sawaniewska-Mochowa Zofia, Bibliografia prac o polszczyźnie kresowej, „Studia nad Polszczyzną Kresową", t. VI, red. J. Rieger, W. Werenicz, Wrocław 1991.

Sawaniewska-Mochowa Zofia, Bibliografia prac o polszczyźnie kresowej za lata 1989-1993 (z uzupetnieniami do roku 1988), „Studia nad Polszczyzną Kresową”, t. VIII, red. J. Rieger, Wrocław 1995.

Sawaniewska-Mochowa Zofia, Bibliografia „kowieńska”, [w:] Nazwy mówią, red. M. PająkowskaKensik, M. Czachorowska, Bydgoszcz: Wydawnictwo Akademii Bydgoskiej im. Kazimierza Wielkiego, 2004.

Suter Paul, Alfurkan Tatarski. Der litauisch-tatarische Koran-Tefsir, Köln-Weimar-Wien: Köln-Böhlau Verlag, 2004.

Talko-Hryncewicz Julian, Muślimowie, czyli tak zwani Tatarzy litewscy, Kraków: Księgarnia geograficzna „Orbis”, 1924.

Тарелка Міхась, Сынкова Ірына, Адкуль пайшлі ідаль, Мінск: Тәхналогія, 2009.

Уста Халим Ибрагим, Исторический обзор первых подстрочных переводов корана (на материале тюрских языков), [w:] Tiurku Istorija ir Kultūra Lietuvoje. Turks' History and Culture in Lithuania. История и Культура Тюрков в Аитве, red. T. Bairašauskaite, G. Miškiniené, Vilnius: Vilniaus Universiteto Leidykla, 2014.

Wójcik Zbigniew, Filomacki przekład Alkoranu dla Tatarów nowogródzkich, „Literatura Ludowa” 1995, XXXIX, nr 3.

Zajączkowski Ananiasz, Orient jako źródło inspiracji w literaturze doby mickiewiczowskiej, Warszawa: Państwowy Instytut Wydawniczy, 1955. 